\title{
Investigasi Perbandingan Posisi Rectangular Flat Plate Vortex Generator dengan Posisi Straight pada Wing Airfoil NACA 43018
}

\author{
Setyo Hariyadi S.P. ${ }^{1,2}$, Wawan Aries Widodo ${ }^{2}$, Bambang Junipitoyo ${ }^{1}$, Wiwid Suryono ${ }^{1}$, Supriadi ${ }^{1}$ \\ ${ }^{1)}$ Politeknik Penerbangan Surabaya \\ Jl. Jemur Andayani I/73, Surabaya 60236 \\ ${ }^{2)}$ Laboratorium Mekanika Fluida, Departemen Teknik Mesin, FTI, ITS \\ Jl. Arief Rahman Hakim, Surabaya 60111 Indonesia \\ Email: hudzaifahsetyo@gmail.com
}

\begin{abstract}
Abstrak
Pesawat terbang merupakan aplikasi ilmu mekanika fluida yang sangat memperhatikan aspek aerodinamika karena berkaitan dengan performa pada penerbangan. Satu hal penting yang harus diperhatikan dalam pendesainan suatu pesawat yaitu pemilihan airfoil dan modifikasinya. Modifikasi airfoil dilakukan untuk menunda separasi aliran dan meningkatkan performa airfoil, salah satunya dengan vortex generator. Modifikasi pada airfoil dilakukan untuk meningkatkan performansi dari airfoil. Hal ini dapat diindikasikan dengan tertundanya separasi aliran yang melintasi permukaan atas dari airfoil. Dengan tertundanya separasi ini maka gaya lift akan semakin besar dan gaya drag akan semakin kecil. Penelitian sebelumnya menunjukkan bahwa penambahan vortex generator pada permukaan atas airfoil dapat menunda terjadinya separasi aliran. Hal ini disebabkan aliran lebih tahan melawan gaya gesek dan adverse pressure gradient.

Topik yang dikaji dalam penelitian ini adalah aliran melintasi airfoil NACA 43018 dengan penambahan vortex generator. Airfoil NACA 43018 digunakan pada sayap pesawat terbang ATR 72. Tujuan penelitian ini adalah untuk membandingkan karakteristik aliran fluida dengan dan tanpa penambahan vortex generator. Profil vortex generator yang digunakan adalah rectangular flat plate vortex generator dengan konfigurasi straight dan ditempatkan pada $x / c=10 \%$ dan $20 \%$ arah chord line dari leading edge. Variasi yang digunakan adalah bilangan Reynolds $(R e)$ dan sudut serang $(\alpha)$ pada airfoil. Kecepatan freestream yang digunakan yaitu kecepatan $12 \mathrm{~m} / \mathrm{s}$ atau $R e=7,65 \times 10^{5}$ dan kecepatan $17 \mathrm{~m} / \mathrm{s}$ atau $\operatorname{Re}=9 \times 10^{5}$, dan pada sudut serang $(\alpha) 0^{\circ}, 3^{\circ}, 6^{\circ}, 9^{\circ}, 12^{\circ}, 15^{\circ}, 19^{\circ}$, dan $20^{\circ}$. Parameter yang dievaluasi meliputi koefisien tekanan $(C p)$, profil kecepatan, lift, $d r a g$, dan rasio $C_{L} / C_{D}$.

Hasil penelitian ini menunjukkan bahwa terjadi peningkatan performansi dari airfoil NACA 43018 dengan penambahan vortex generator dibandingkan dengan tanpa vortex generator. Adanya vortex generator, dapat menunda terjadinya separasi. Dengan penambahan vortex generator terjadi peningkatan lift sekitar 5\% dan menaikkan drag sekitar 1,5\%. Rasio $C_{L} / C_{D}$ meningkat sekitar $5 \%$.
\end{abstract}

Kata kunci: airfoil NACA 43018, vortex generator, koefisien tekanan, lift, drag

\section{PENDAHULUAN}

Pesawat terbang dirancang sedemikian rupa sehingga hambatan udaranya sekecil mungkin. Dari semua desain pesawat, pasti yang diinginkan adalah lift setinggi-tingginya. Untuk mendapatkan lift yang setinggi-tingginya membutuhkan angle of attack $(\alpha)$ yang tinggi juga. Pada saat $\alpha$ tinggi akan menimbulkan gaya drag yang meningkat juga. Salah satu cara untuk mengatasi gaya drag ini adalah menggunakan vortex generator pada bagian tertentu dari pesawat terbang. Vortex generator menunda terjadinya separasi aliran dan aerodynamic stalling sekaligus menjaga aliran terutama di atas wing/sayap agar tetap steady.

Vortex generator $(V G)$ adalah suatu alat yang dapat mempercepat terjadinya transisi dari laminar boundary layer menjadi turbulen boundary layer. Ada berbagai jenis vortex 
generator antara lain vane, delta wing, dan triangular. Aliran turbulen boundary layer yang dibangkitkan ini diharapkan dapat meningkatkan momentum aliran sehingga lebih mampu menahan adverse pressure gradien dan menunda separasi. Vortex generator ini sudah banyak diterapkan di berbagai macam pesawat komersial. Salah satu yang menggunakannya adalah pada pesawat boeing yaitu menggunakan vortex generator jenis plat datar.

Penelitian terdahulu yang telah dilakukan oleh Lin (1999) adalah riset mengenai curve edge untuk menunda separasi aliran. Penambahan vortex generator dilakukan pada sebuah luasan dengan konfigurasi slat dan flap. Lin menggunakan Vortex Generator pada slat, $25 \%$ dari total cord dan pada flap. Kesimpulan yang didapat adalah pada baseline (Tanpa $V G$ ) maka separasi terjadi pada $x / c=40 \%$. Apabila diletakkan $V G$ pada $x / c=20 \%$ maka aliran attach sampai dengan flap.

Zhen, dkk (2010) meneliti pengaruh vortex generator pada allianced unmanned developmental research aircraft (Aludra) unmanned aerial vehicle (UAV). Vortex generator yang dipakai adalah triangular dan rectangular element. Hasil dari penelitian ini antara lain menunjukkan rectangular dan curve edge $V G$ lebih efektif daripada triangular $V G$ dalam peningkatan lift force pada wing. Selain itu rectangular dan triangular $V G$ menghasilkan drag yang lebih besar dari $V G$ jenis curve edge.

Anand dkk (2010) meneliti efektifitas vortex generator jenis counter rotating triangle vortex generator. Vortex generator ini diletakkan pada $10 \%$ chord length pada airfoil jenis NACA 0012 dengan angle of attack $11^{\circ}$ dan $16^{\circ}$ menggunakan $R e=5,5 \times 10^{5}$. Berdasarkan penelitian ini didapatkan hasil yaitu penggunaan vortex generator dapat menunda separasi pada dinding airfoil.

Berdasarkan hasil kajian dari beberapa penelitian tersebut di atas, muncul gagasan baru untuk meningkatkan performance vortex generator dalam meningkatkan lift force pada wing dengan variasi peletakan $V G$ terhadap leading edge terutama pada penggunaan pesawat komersial. Untuk tujuan ini maka diadakan pengujian pada model NACA 43018 yang digunakan pada pesawat ATR 72 seri 500-600 dengan penggunaan vortex generator berbentuk rectangular.

\section{METODOLOGI}

\subsection{Penelitian Eksperimen}

Model sayap yang digunakan dalam percobaan ini adalah sayap dengan profil Airfoil NACA 43018 dengan modifikasi penambahan vortex generator bagian atas untuk mengetahui pengaruh penambahan vortex generator dibandingkan tanpa model sayap tanpa vortex generator.
Jenis airfoil dan kondisi ruangan
Jenis airfoil : NACA 43018
Tekanan ruangan $\quad: 760 \mathrm{mmHg}$
Temperatur ruangan $: 30^{\circ} \mathrm{C}$

Tabel 1. Parameter Vortex Generator 43018

\begin{tabular}{|c|l|l|c|}
\hline Paramater & \multicolumn{1}{|c|}{ Eksperimen } & \multicolumn{1}{|c|}{ Simulasi } & \\
\hline Shape & Rectangular & Rectangular & \\
\hline $\mathrm{H}$ & $0.0086 \mathrm{c}$ & $0.0086 \mathrm{c}$ & Anand (2010) \\
\hline $\mathrm{l} / \mathrm{h}$ & 3 & 3 & Lin (1999) \\
\hline $\mathrm{A}$ & $\begin{array}{l}0^{\circ}, 3^{\circ}, 6^{\circ}, 9^{\circ}, 12^{\circ}, 15^{\circ}, \\
19^{\circ}, \text { dan } 20^{\circ}\end{array}$ & $\begin{array}{l}0^{\circ}, 3^{\circ}, 6^{\circ}, 9^{\circ}, 12^{\circ}, 15^{\circ}, \\
19^{\circ}, \text { dan } 20^{\circ}\end{array}$ & \\
\hline $\mathrm{x} / \mathrm{c}$ & $10 \%, 20 \%$ & $10 \%, 20 \%$ & H. Shan et al, (2007) \\
\hline $\mathrm{C}$ & $200 \mathrm{~mm}$ & $1000 \mathrm{~mm}$ & Anand (2010) \\
\hline $\mathrm{D}$ & $0,182 \mathrm{c}$ & $0,182 \mathrm{c}$ & \\
\hline Susunan & Straigh & Straigh & \\
\hline $\mathrm{V}_{\infty}$ & $12 \mathrm{~m} / \mathrm{s}, 17 \mathrm{~m} / \mathrm{s}$ & $12 \mathrm{~m} / \mathrm{s}, 17 \mathrm{~m} / \mathrm{s}$ & \\
\hline
\end{tabular}




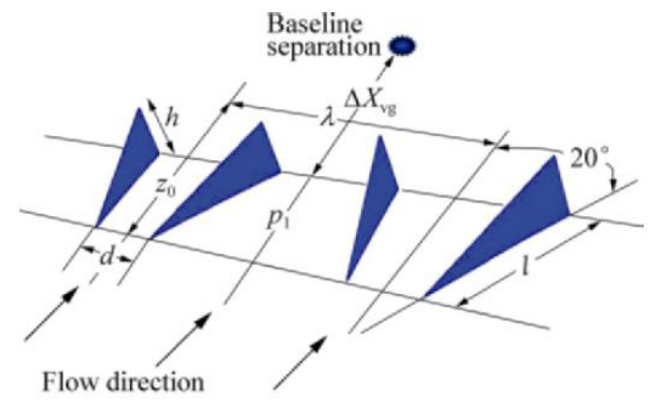

Gambar 1. Definisi vane-type passive VG devices (Zhen, dkk, 2010)

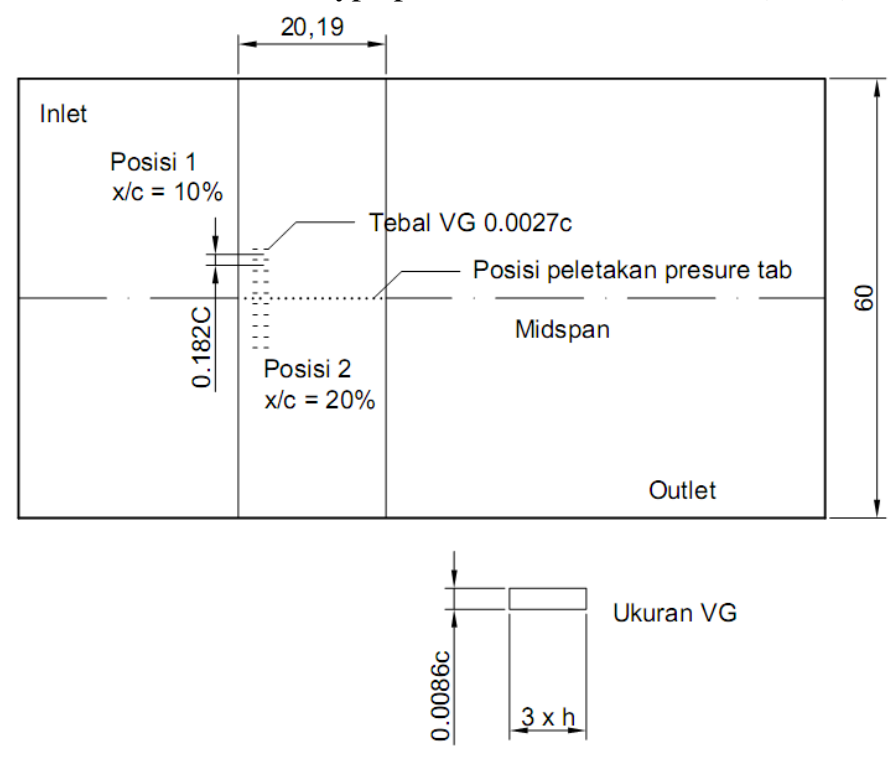

Gambar 2. Posisi peletakan $V G$ pada penelitian eksperimen

Penelitian numerik dilakukan dengan menggunakan metode Computational Fluid Dynamics (CFD) dengan software Fluent 6.3.26. dan dengan software GAMBIT 2.4.6 untuk membuat model awal dan melakukan diskritisasi (meshing) pada model tersebut. Prosedur yang dilakukan pada penelitian numerik adalah sebagai berikut:

\subsection{Simulasi Numerik}

\subsubsection{Tahap pre-processing menggunakan software GAMBIT 2.4.6}

a) Membuat model dan geometri berupa airfoil dengan bentuk

b) Membuat meshing volume dengan tipe hexahedral-map. Meshing yang digunakan adalah dengan grading pada arah vertikal dengan distribusi mesh yang semakin rapat pada semua dinding, baik diverging wall maupun straight wall. Hal ini dilakukan sebagai efek adanya wall function.

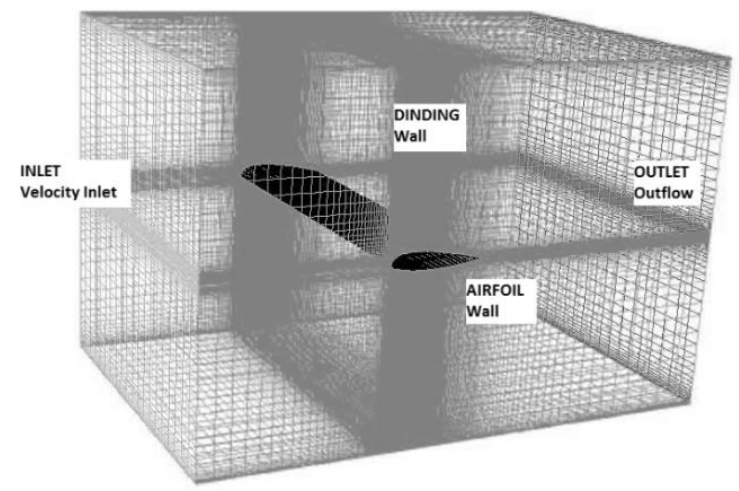

Gambar 3. Meshing dan Domain Pemodelan Airfoil 3D dengan tipe hexahedral-map pada Fluent 
c) Mendefinisikan kondisi batas yaitu penentuan parameter-parameter dan batasan yang mungkin terjadi pada aliran. Kondisi batas inlet adalah velocity inlet. Kondisi batas outlet adalah outflow. Upper surface dan lower surface dari airfoil adalah wall. Berikut adalah dimensi dan boundary condition dari hasil Gambit.

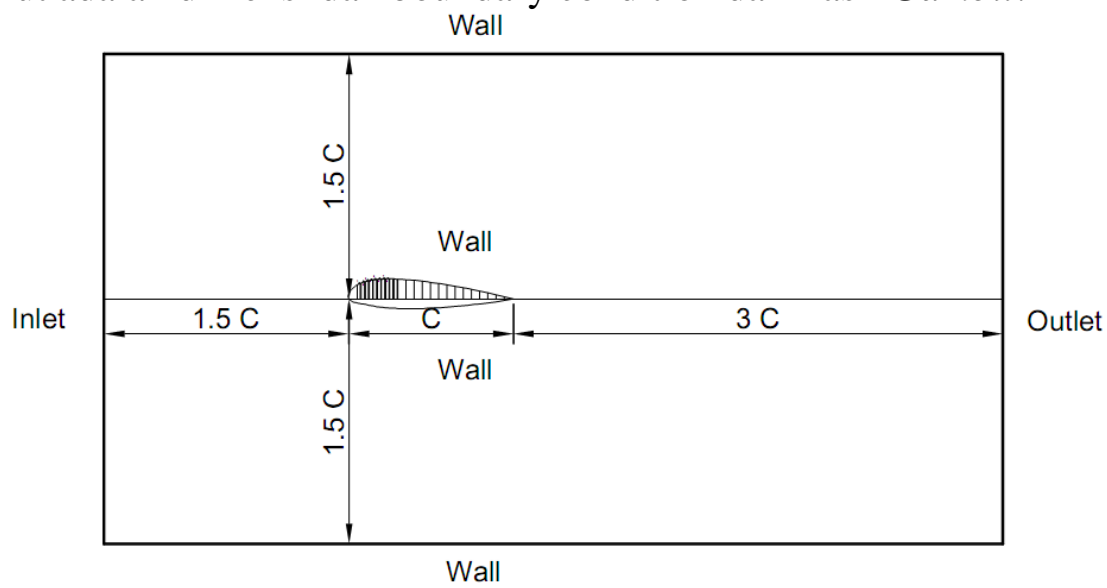

Gambar 4. Dimensi pemodelan dan kondisi latar (Mulvany, 2004)

d) Pada plain airfoil, untuk memudahkan analisis maka potongan/iso surface diletakkan pada mid span yaitu pada $\mathrm{z}=2$. Sedangkan pada airfoil yang menggunakan vortex generator, potongan/iso surface diletakkan pada $\mathrm{z}=1,9075$.

\subsubsection{Tahap post-processing menggunakan software Fluent 6.3.26}

Langkah awal setelah masuk pada software Fluent dilakukan read untuk data hasil eksport GAMBIT. Kemudian dilakukan pengecekan grid. Setelah itu ditentukan skala. Pada penelitian ini menggunakan skala dalam mm.

Dalam penggunaan Fluent 6.3.26 memerlukan keakuratan data baik pada langkah post processing maupun preprocessingnya. Langkah grid independensi diperlukan untuk menentukan tingkat serta struktur grid terbaik dan terefisien agar hasil pemodelan mendekati sebenarnya. Tabel 2 menampilkan variasi meshing model uji 3 dimensi pada bilangan Reynolds 765000 . Berdasarkan tabel 2 nilai $C_{D}$ yang cenderung konstan terjadi pada Meshing A dan Meshing B. Nilai error yang paling kecil dengan hasil penelitian Eastman dan Abbot (1935) adalah Meshing A. Salah satu pertimbangan dalam melakukan simulasi numerik adalah waktu dan memori yang digunakan, maka meshing yang digunakan untuk simulasi selanjutnya adalah Meshing A.

Tabel 2. Analisa grid independensi airfoil 430182 Dimensi tanpa Vortex Generator

\begin{tabular}{|c|c|c|c|c|}
\hline Jenis Meshing & Jumlah Node & $C_{D}$ & \multirow{2}{*}{$\begin{array}{c}C_{D} \text { Percobaan Eastman } \\
\text { dan Abbot (1935) }\end{array}$} & Error \\
\cline { 1 - 2 } Meshing A & 504.086 & 0.08 & & 0.04 \\
\cline { 1 - 2 } Meshing B & 639.000 & 0.15 & & 0.11 \\
\cline { 1 - 2 } Meshing C & 832.000 & 0.216 & & 0.176 \\
\hline Meshing D & 862.642 & 0.297 & & 0.176 \\
\hline
\end{tabular}

Pada langkah ini dilakukan pemodelan karakteristik aliran, meliputi pemilihan model solver dan penentuan turbulence model yang digunakan. Solver yang digunakan adalah unsteady. Turbulence model yang digunakan untuk airfoil ini adalah model $k-\varepsilon$ Realizable berdasarkan penelitian Mulvany et al (2004). 


\section{HASIL DAN PEMBAHASAN}

\subsection{Hasil dan Pembahasan}

\subsubsection{Analisis Koefisien Drag $\left(C_{D}\right)$ dan Koefisien Lift $\left(C_{L}\right)$}

Gambar 5 menunjukkan perbandingan $C_{D}$ antara plain airfoil dan airfoil dengan penambahan vortex generator dari hasil numerik pada penelitian ini. Sedangkan pada gambar 6 ditunjukkan perbandingan $C_{L}$ antara plain airfoil dan airfoil dengan penambahan vortex generator. Dari hasil simulasi dengan penambahan vortex generator didapatkan nilai $C_{D}$ pada $\operatorname{Re} 7.65 \times 10^{5}$ dengan $\alpha=0^{0}$ sebesar $0.0483, \alpha=3^{0}$ sebesar 0.0724 sedangkan $\alpha=$ $6^{0}$ sebesar 0.0774. Nilai tersebut lebih besar bila dibandingkan dengan simulasi 3D plain airfoil, yaitu $1,3 \%$ pada $\alpha=0^{0}, 19,3 \%$ pada $\alpha=3^{0}, 6,3 \%$ pada $\alpha=6^{0}$. Hal ini diakibatkan karena adanya pengaruh dari vortex generator yang dipasang pada airfoil. Pemasangan vortex generator mempercepat perubahan aliran dari aliran laminar menjadi aliranturbulen, sehingga aliran yang melewati permukaan atas airfoil dengan pemasangan vortex generator memiliki kecepatan yang lebih tinggi bila dibandingkan plain airfoil. Kenaikan sudut serang menyebabkan kenaikan lift dan juga diiringi peningkatan drag. Pengaruh variasi bilangan $R e$ terhadap gaya drag pada sudut serang yang sama yaitu semakin besar Re maka akan semakin kecil gaya drag nya, karena bilangan Re yang tinggi memiliki momentum yang lebih tinggi sehingga separasi bisa ditunda dan gaya drag akan kecil. Pengaruh penambahan vortex generator paling signifikan terjadi pada sudut serang $6^{0}$ yaitu berupa penurunan $C_{D}$ pada $R e=$ $7.65 \times 10^{5}$ sebesar $6.4 \%$, sedangkan pada $R e=9 \times 10^{5}$ sebesar $10,8 \%$.

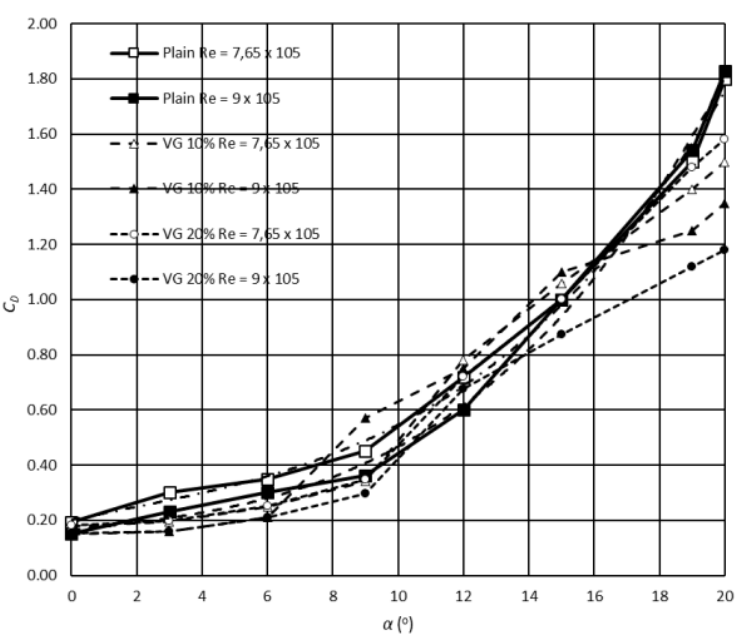

Gambar 5. Koefisien drag $\left(C_{D}\right)$ vs $\alpha$ pada plain airfoil dan menggunakan $V G$

Dari hasil penelitian numerik, kenaikan $C_{D}$ memiliki tren yang hampir sama dengan hasil penelitian eksperimen pada $R e=7.65 \times 10^{5}$ dan $R e=9 \times 10^{5}$. Seiring dengan kenaikan sudut serang, maka terjadi kenaikan nilai $C_{D}$. Akan tetapi pada sudut serang $6^{0}$ hasil simulasi menunjukkan terjadi penurunan nilai $C_{D}$ sedangkan pada eksperimen peningkatan bilangan $R e$ justru meningkatkan nilai $C_{D}$. Perbedaan ini dikarenakan banyaknya constrain dalam penelitian ini yang mempengaruhi data yangdihasilkan. Konstrain tersebut antara lain jenis model turbulen yang digunakan, kondisi batas yang dipilih maupun tingkat kerapatan dan jenis mesh yang dipakai dalam pemodelan numerik. Perbedaan penggunakaan satu jenis constrain tersebut dapat membedakan antara hasil data numerik yang satu dengan data numerik lainnya 


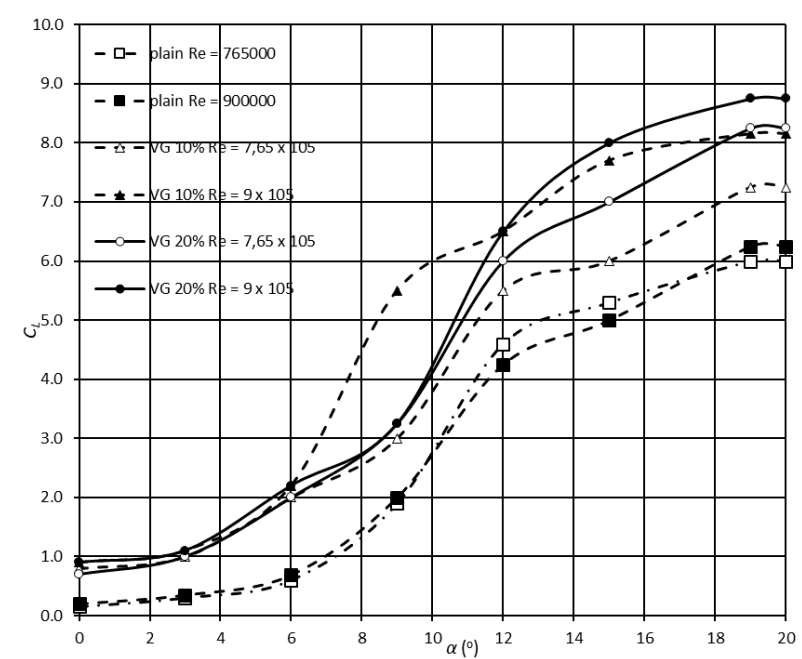

Gambar 6. Koefisien lift $\left(C_{L}\right)$ vs $\alpha$ pada plain airfoil dan menggunakan $V G$

\subsubsection{Analisis Rasio Koefisien Lift dan Drag $\left(C_{L} / C_{D}\right)$}

Gambar 7 menunjukkan perbandingan $C_{L} / C_{D}$ antara plain airfoil dan airfoil dengan penambahan vortex generator dari hasil numerik pada penelitian ini. Dari hasil simulasi, pengaruh penambahan bilangan Reynolds dapat meningkatkan rasio $C_{L} / C_{D}$ baik plain airfoil maupun airfoil dengan $V G$. Momentum aliran pada $R e$ yang lebih tinggi lebih mampu mengatasi tegangan geser dan adverse pressure gradient yang terjadi sehingga separasi semakin tertunda ke belakang.

Sedangkan pengaruh penambahan vortex generator akan menurunkan nilai $C_{L} / C_{D}$ pada sudut serang $0^{0}$ dan $3^{0}$, sedangkan pada sudut serang $6^{0}$ rasio $C_{L} / C_{D}$ akan meningkat dengan penambahan vortex generator. Hal ini diakibatkan pada sudut serang $0^{0}$ dan $3^{0}$ aliran masih mengikuti bodi sehingga gaya drag yang dihasilkan oleh vortex generator itu sendiri lebih dominan. Pada sudut serang $6^{0}$ gaya drag akibat adanya separasi menurun akibat penambahan vortex generator. Bila dibandingkan dengan hasil eksperimen, nilai $C_{L} / C_{D}$ lebih tinggi karena adanya perbedaan nilai $C_{L}$ dan $C_{D}$ yang ada pada pembahasan sebelumnya.

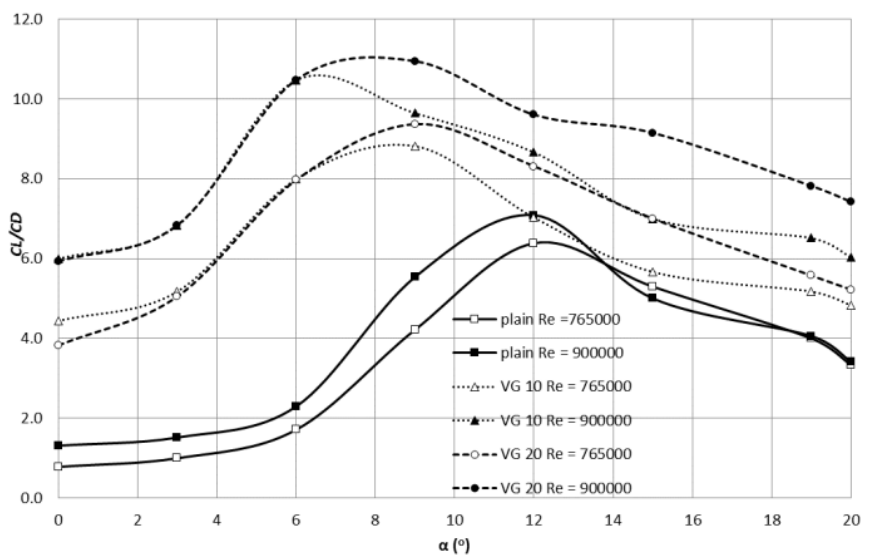

Gambar 7. Perbandingan $C_{L} / C_{D}$ antara plain airfoil dan airfoil dengan vortex generator dari hasil numerik

\subsection{Visualisasi Aliran}

\subsubsection{Vektor Kecepatan pada Plain Airfoil 3D dan Airfoil dengan VG}

Gambar 8 dan 9 menunjukkan vektor kecepatan pada airfoil di daerah upstream dengan pemotongan pada area midspan. Pada airfoil dengan penambahan vortex generator sudut serang $0^{0}$ dan $3^{0}$ belum terlihat terjadi separasi hingga di daerah trailing edge. Hal ini disebabkan dengan adanya vortex generator menambah momentum aliran sehingga aliran 
masih mengikuti kontur bodi airfoil. Momentum aliran yang tinggi mampu melawan gaya geser dan adverse pressure gradient.

Pengaruh penggunaan vortex generator ditunjukkan pada gambar 10 untuk sudut serang $19^{\circ}$. Pada gambar 10 ditunjukkan profil kecepatan pada plain airfoil $\mathrm{z}=2$ (midspan), $\mathrm{x}=2$. Profil kecepatan pada bagian atas cenderung berkurang menandakan pengaruh gaya geser dan adverse pressure gradient.Sedangkan pada posisi yang sama pada gambar 16.b dimana diambil titik $\mathrm{z}=1,9075, \mathrm{x}=2$ yaitu daerah di belakang vortex generator $x / c=0,1$ maka profil kecepatan cenderung ada perbaikan bentuk ke kotak yang menandakan momentum hasil penempatan vortex generator mampu mengatasi gaya geser dan adverse pressure gradient. Demikian juga pada gambar 16.c dimana diambil titik $\mathrm{z}=1,9075, \mathrm{x}=2$ yaitu daerah tepat di belakang vortex generator $\mathrm{x} / \mathrm{c}=0,2$ maka profil kecepatan cenderung berbentuk kotak yang menandakan momentum hasil penempatan vortex generator lebih mampu mengatasi gaya geser dan adverse pressure gradient.

\subsubsection{Velocity Pathline pada Plain Airfoil 3D dan Airfoil dengan VG}

Gambar 11 merupakan visualisasi velocity pathline pada airfoil dengan sudut serang $0^{0}$, dengan plain airfoil ditunjukkan pada gambar 11(a) serta airfoil dengan penambahan vortex generator $10 \%$ dan $20 \%$ dengan $R e=7,65 \times 10^{5}$ ditunjukkan pada gambar 11 (b) dan (c). Visualisasi Pathline pada plain airfoil pada gambar 11(a), (b), (c) menunjukkan bahwa aliran mengalami distribusi merata di sepanjang span serta masih cenderung mengikuti kontur bodi sampai trailing edge. Gambar 11(d) merupakan visualisasi velocity pathline pada airfoil dengan sudut serang $15^{\circ}$ dengan plain airfoil serta airfoil dengan vortex generator $10 \%$ dan $20 \%$ ditunjukkan pada gambar 11 (e) dan (f) pada $R e=7,65 \times 10^{5}$. Pathline pada plain airfoil pada gambar 11(d) menunjukkan bahwa aliran kecepatannya menurun dan mengalami separasi terjadi pada $x / c=0.6$. Separasi inilah yang ditunjukkan pada velocity Pathline terlihat seperti vortex di sepanjang span airfoil. Pathline pada airfoil dengan vortex generator $10 \%$ seperti pada gambar 11(e) menunjukkan dengan penambahan VG 10\% separasi mundur ke arah trailing edge karena dengan penambahan $V G$ aliran mengalami peningkatan kecepatan setelah melewati vortex generator. Demikian juga dengan penambahan $V G$ pada $x / c=0,2$ separasi mundur ke arah trailing edge karena dengan penambahan $V G$ aliran mengalami peningkatan kecepatan setelah melewati vortex generator.

Gambar $11(\mathrm{~g})$ merupakan visualisasi velocity pathline pada airfoil dengan sudut serang $19^{0}$ dengan plain airfoil serta airfoil dengan vortex generator $10 \%$ dan $20 \%$ ditunjukkan pada gambar $11(\mathrm{~h})$ dan (i) pada $R e=7,65 \times 10^{5}$. Pathline pada plain airfoil pada gambar 11(j) menunjukkan bahwa aliran kecepatannya menurun dan mengalami separasi terjadi pada $x / c=0.6$. Separasi inilah yang ditunjukkan pada velocity pathline terlihat seperti vortex di sepanjang span airfoil. Pathline pada airfoil dengan vortex generator $10 \%$ seperti pada gambar 11(i) menunjukkan dengan penambahan VG $10 \%$ aliran attach kembali ke permukaan airfoil ditunjukkan dengan warna yang lebih muda di bawah separasi dan separasi mundur ke arah trailing edge karena dengan penambahan $V G$ aliran mengalami peningkatan kecepatan setelah melewati vortex generator. Demikian juga dengan penambahan $V G$ pada $x / c=0,2$ separasi mundur ke arah trailing edge karena dengan penambahan $V G$ aliran mengalami peningkatan kecepatan setelah melewati vortex generator. Di samping itu aliran attach kembali ke permukaan airfoil.

\section{PENUTUP}

\subsection{Kesimpulan}

Dari analisis hasil eksperimen dan simulasi dengan pengukuran koefisien lift, koefisien drag, dan post processing pada airfoil NACA 43018:

1. Koefisien lift pada plain airfoil dan airfoil dengan vortex generator terus meningkat seiring dengan peningkatan sudut serang sampai pada $\alpha=19^{\circ}$, kemudian terjadi stall 
yang diindikasikan dengan menurunnya $C_{L}$ sampai pada $\alpha=20^{\circ}$ pada kedua Reynolds Number.

2. Koefisien drag pada plain airfoil dan airfoil dengan vortex generator terus meningkat seiring dengan peningkatan sudut serang dari $\alpha=0^{\circ}$ sampai pada $\alpha=20^{\circ}$ pada kedua Reynolds Number.

3. Koefisien lift pada plain airfoil dan airfoil dengan vortex generator terus meningkat seiring dengan peningkatan sudut serang dari $\alpha=0^{\circ}$ sampai pada $\alpha=20^{\circ}$ pada kedua Reynolds Number.

4. Penambahan vortex generator dapat meningkatkan performa dari airfoil dilihat dari distribusi $C_{L} / C_{D}$ yang semakin meningkat pada kedua Reynolds number.

\section{DAFTAR PUSTAKA}

Anderson, J. D., Jr. (2001). Fundamentals of Aerodynamics, $3^{\text {rd }}$ edition. Mc Graw Hill, Inc., Jacobs, Eastman N., Abbott, Ira H. (1935), Airfoil Section Data Obtained In The NACA Variable-Density Tunnel As Affected by Support Interference And Other Correction, National Advisory Committee For Aeronautics, Report 669

Lin, John. C.,(2002), Review of research on low-profile vortex generators to control boundary-layer separation Flow, Physics and Control Branch, NASA Langley Research Center, Hampton, VA 23681-2199, USA

H. Shan et al.(2007), Numerical Study of Passive and Active Flow Separation Control Over NACA 0012 Airfoil, Science Direct

Zhen, Tan Kar, Ahmad, Kamarul Arifin., Zubair, Muhammed.,(2010), Experimental and Numerical Investigation of the Effects of Passive Vortex Generators on Aludra UAV Performance, Journal of Aeronautics, School of Aerospace Engineering, University Sains Malaysia, NibongTebal 14300, Malaysia

Anand, U., Shudakar, Y., Thileopanragu, R., Gopinathan, V.T., dan Rajasokar, R. (2010), Passive Flow Control Over NACA 0012 Airfoil Using Vortex Generator. India: Department of Aerospace Engineering IIT Madras.

Mulvany, Nicholas et. al.(2004), Steady State Evaluation of Two Equation RANS Turbulence Models for High Reynolds Number Hydrodynamic Flow Simulations

Fluent Inc.(2000), Gambit Tutorial Guide

Fluent Inc.(2009), FLUENT 6.3. User Guide 